\title{
Edouard Poty: a bio- and bibliography
}

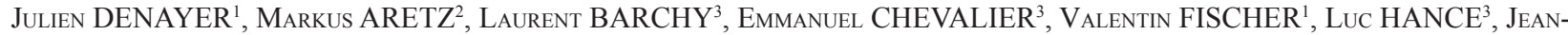 \\ MARC MARION $^{1}$, BERNARD MOTTEQUIN ${ }^{4}$
}

${ }^{1}$ Université de Liège, Département de Géologie, Evolution and Diversity Dynamics Lab, Quartier Agora, B18, Allée du Six-Aô̂t, B-4000 Liège, Belgium.

${ }^{2}$ Université de Toulouse (UPS), Géosciences Environnement Toulouse (OMP), Avenue Edouard Belin, 14, F-31400 Toulouse, France.

${ }^{3}$ Carmeuse, Boulevard de Lauzelle, 65, B-1348 Louvain-la-Neuve, Belgium.

${ }^{4}$ Institut royal des Sciences naturelles de Belgique, Earth and History of Life, rue Vautier 29, 1000 Brussels, Belgium.

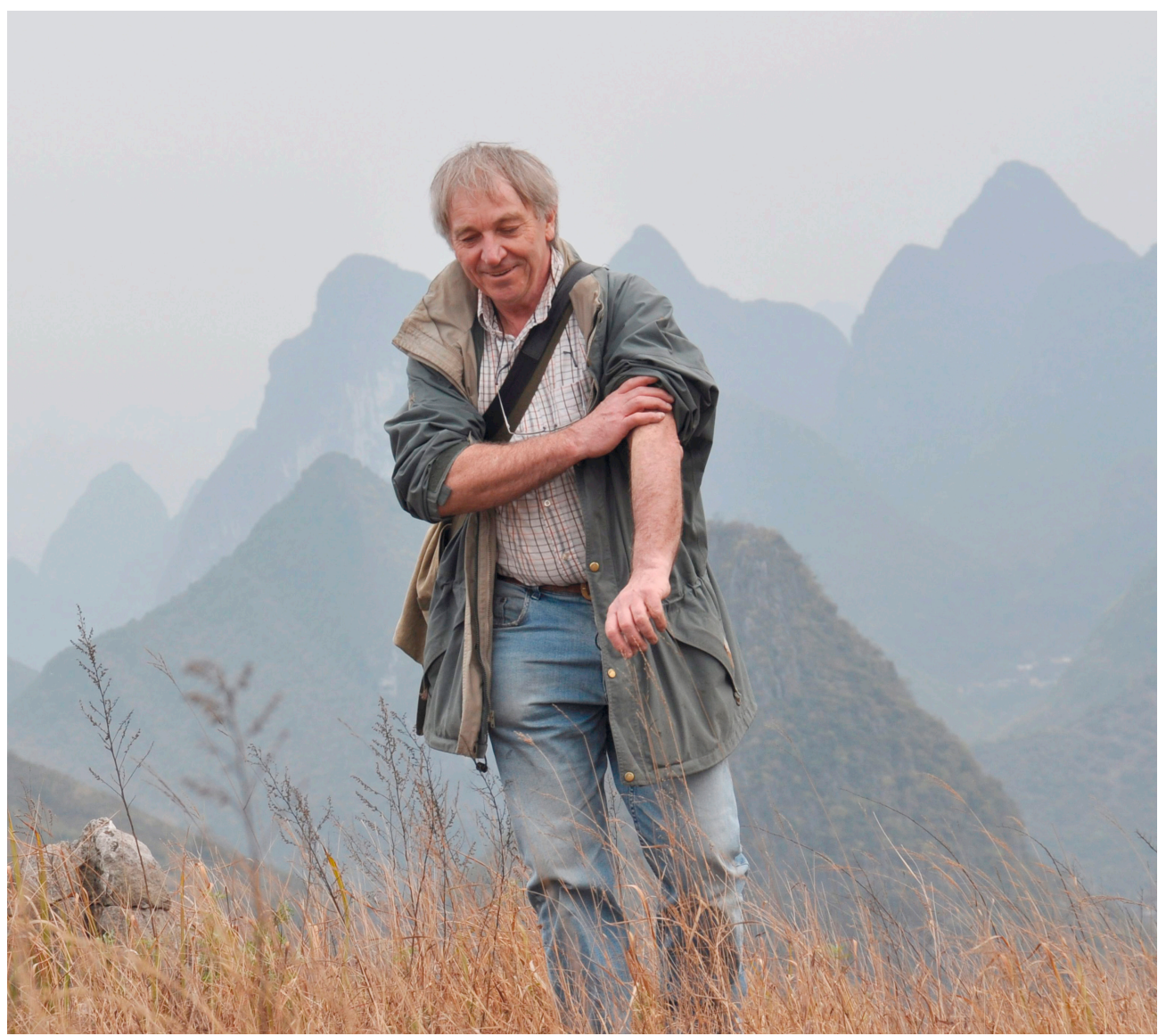

'Generalist' is a qualifying word that best describes Edouard - 'Eddy' - Poty in term of knowledge. He is not just a wellknown palaeontologist. Passionate in all branches of geology, he developed an exceptional background and became one of the very few feeling comfortable out of his area of expertise and capable of seeing the bridges connecting field observations. His research and publications do not necessarily reflect his wide knowledge but those who have or have had the chance to work with him know that Eddy is a living encyclopedia. Moreover, his interest largely crosses over the borders of geology and he can with erudition discuss archaeology, history, architecture, volcanoes, anthropology, literature, cuisine and wine! To understand the man, let us visit his career.

Born in 1949 in Seraing, near Liège in Belgium, the young Eddy quickly found his interest in fossils after he discovered brachiopods in the excavation made for the construction of a bridge in Esneux. His first fossils... and the beginning of a lifelong passion for geology. During his childhood and teenage years, he used to search for fossils and minerals while on holiday with his parents, but also around Liège.

In 1967, he entered the University of Liège to study geology (at that time 'Geological and Mineralogical Sciences') and learned from Prof. Bellière, Michot and Ubaghs among others. Four years later he presented his master's thesis on Viséan corals. His scientific career was not yet cast because military service was compulsory... but Eddy was not made for the uniform and the discipline which go along with the military. We find him back enrolled in civilian service as a mathematics teacher in Algeria. He spent a year teaching during the week and travelling through the desert during week-ends and holidays to explore the mountains and to collect fossils! Enchanted by Algeria, Eddy would reiterate the experience in the Congo and settled for two more years in Bounia. His life there, if his uncountable anecdotes are true, was epic and amazing.

Back in Belgium in 1974, Eddy joined the University of Liège, where for two years he taught the practical classes in geology at the geography department for Prof. Macar. In 1976 he returned to the geology department with an IRSIA research grant to start a $\mathrm{PhD}$ under the direction of Prof. Ubaghs. He focused on a group untouched since the 1920's: the Lower Carboniferous rugose corals. Thus started his long-lasting and very friendly collaboration with Raphaël - 'Raph' - Conil and his team at the University of Louvain-la-Neuve. After his PhD in 1980 (for which he was laureate of the Belgian Royal Academy) he kept his deep interest in research for corals, first as an assistant and later assistant lecturer. In 1987 Eddy succeeded Prof. Ubaghs as Professor of Palaeontology at the University of Liège. This was a new start again, making possible new collaborations to revisit the Carboniferous of Belgium and surrounding areas. No need to look to his mountain boots to understand that Eddy is a good 


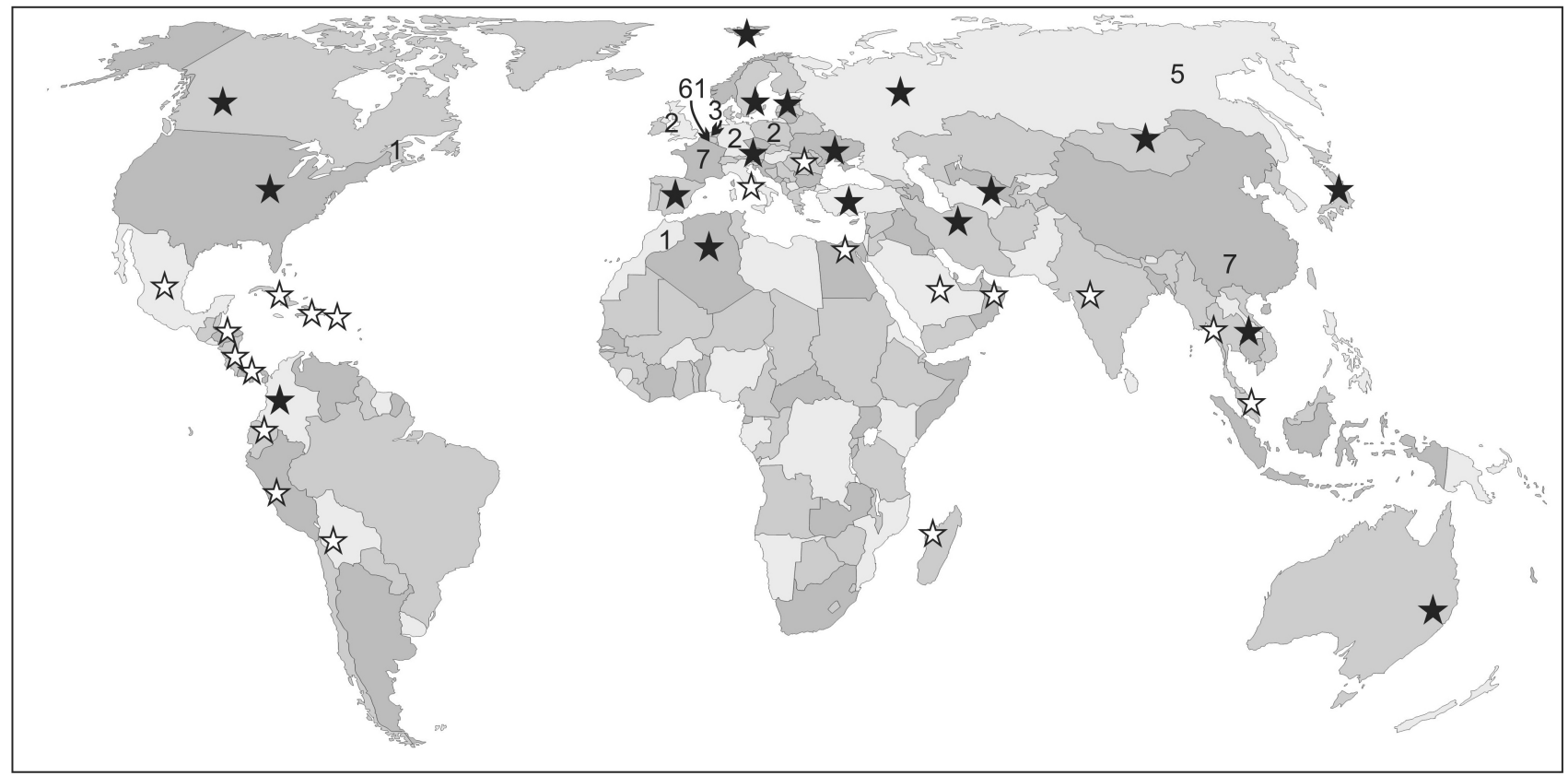

Figure 1. World Map of Edouard Poty's publications and collections. Cyphers indicate the number of publications for each country. Black stars stand for Palaeozoic corals from Eddy's collection. White stars stand for other corals from his collection.

field geologist who enjoys describing, measuring and sampling sections. Very few outcrops escaped to his hammer in Belgium and abroad. Step by step and country after country, he gathered what was going to be one of the largest - if not the largest collection of Carboniferous corals worldwide with more than 20 heavy cubic-metres of hand-specimens and 30,000 thin sections (and an unknown number of unclassified ones) from more than 60 regions (Fig. 1), each sample localized and stratigraphically positioned. Hundreds of those samples are rare specimens or specimens from localities that are no longer accessible and thus making this collection even more valuable. Thanks to many worldwide collaborations - several being running for more than 40 years on - Eddy gathered an incredible knowledge on the Carboniferous of the world. In 2015, his research on corals was rewarded by the highest prize in this field: the Henry Milne Edwards Medals from the Association for the Study of Fossil Cnidaria and Porifera.

Scientific research was very important for Eddy. However, he never stopped teaching geology, palaeontology and evolution to hundreds of passionate and less passionate students in various degree programs and arousing the interest of geologists-tobe. Humble and accessible, he was never too busy with his projects to open his door to undergraduate, graduate and $\mathrm{PhD}$ students. In 40 years, he directed more than 50 master's and $8 \mathrm{PhD}$ theses covering an incredibly wide area of topics, from Carboniferous rugose corals to Quaternary cave sedimentology and from Devonian fishes to Cretaceous ichthyosaurs. Science will remember the outcomes Eddy made on the understanding of fossil corals, litho- and biostratigraphy, sequence stratigraphy and pioneer works on event-stratigraphy across the FrasnianFamennian boundary, Devonian-Carboniferous boundary and through the Early Carboniferous. What many students will remember are his ability to decode structures in the field and give extremely valuable insights on any palaeontological issue... as well as his impressive climbing and story-telling capabilities.

In addition to his academic and scientific career, Eddy conducted a vast body of expert work for industry, mainly for quarrying companies and lime producers. His expertise on pure carbonate led him all around the globe where he conducted field studies in any field and throughout the geological time scale from the Precambrian to the Pleistocene. Between 1995 and 2001, his collaborators and himself were chosen by the regional government to establish an updated database of industrial rock production and to safeguard resources in southern Belgium. This resulted in a thousand-page report summarized in a book (Poty \& Chevalier, 2004) which is still the standard reference for the extractive industries of Belgium. An update of the database (more than 1500 sites) was conducted by him and his team and was followed by a socio-economic analysis of the quarrying industry. In parallel, Eddy led the revision of the geological maps of southern Belgium between 1991 and 2014, a program that still goes on today through his collaborators at the University of Liège. Eddy also performed so many expert assessments at all scales and for so many purposes (quarries, oil geology, land stability, archaeology, geo-tourism, etc.) that it is virtually impossible to list them here.

Eddy has been a member of the Société géologique de Belgique and Geologica Belgica since 1968 and was assistant secretary of this society from 1983 to 1994 . He belongs to several scientific societies, including the International Association for the Study of Fossil Cnidaria and Porifera from 1975 and was chairman organizer for the XIth symposium of the association in 2011 in Liège (Aretz et al., 2011; Aretz \& Poty, 2011; Denayer et al., 2012). He has been active in the International Commission of Carboniferous Stratigraphy since the early 1980's and serves as a voting member of this commission since 2007 . He took part in the creation of several local scientific groups of various purposes. Relentless field worker, Eddy led uncountable field trips in Belgium for Belgian and international scientific societies. Nobody who attended one of those can forget the lunch breaks... No doubt that he will continue to organize field meetings in the forthcoming years for the benefit of everyone.

He participated actively to the life of the Palaeontological Group and Geology Department of the University of Liège and was president of the latter from 1992 to 1995 and from 2001 to 2005. Between 1999 and 2008 he was head of the working group of the Geological Map of Wallonia for which he employed 10 field geologists from five Belgian universities and research institutes. At the same period, he was head and coordinator of the Walloon Ground Water Observatory. His public life also includes a seat at the selection committee of the Royal Belgian Institute of Natural Sciences, at the Clément Guion medal selection board, at the scientific committee of the Geological Map of Wallonia and to the Belgian national stratigraphic committee (he was head of the Carboniferous sub-commission). He acted - and still acts as a reference person for geological issue for many and various communities and administrations. Eddy was also a pioneer of the development of geo-sites in Belgium and contributed to their preservation (e.g. Mottequin et al., 2012).

Because of his vast knowledge of geology and palaeontology in any context, age or phylum, Eddy was, is and will remain a mentor for his collaborators and, hopefully, will continue to inspire future generations of scientists. 
Figure 2. Stratigraphical and topical publications of Edouard Poty between 1975 and 2015. DCB: DevonianCarboniferous boundary, FFB: Frasnian-Famennian boundary.

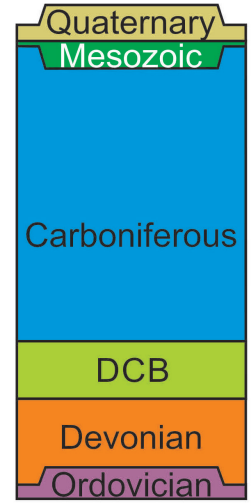

Timeless

\section{Comments and selected bibliography (Fig. 2)}

It is not the aim to present and discuss Eddy's entire publication list of more than 100 papers and more than 200 conference abstracts and field guide books. But it is worthwhile commenting on some of them. His earliest publications deal with the systematics of Viséan rugose corals from Belgium (Poty, $1975 \mathrm{a}, \mathrm{b}, \mathrm{c})$. They initiated the work for his PhD thesis that was subsequently published (Poty, 1981) and which is still a highly cited reference. Three major references need to be cited for his work on evolution of Palaeozoic corals: Poty (1993) for the recognition of heterochrony in the evolution of lithostrotionids; Poty (2007) for the palaeogeographic influence on the evolution of fossil assemblages; and Poty (2010) for an overview of the intrinsic processes involved in the evolution of corals.

Going back to his time in the geography department, Eddy developed a peculiar interest on palaeokarst associated to block faulting systems of the Visé area (Poty, 1980, 1982). In the early 1980's, Eddy was involved in a highly successful exchange program between Belgium and the Soviet Union, which allowed him the collection and study of the Siberian Far-East (Omolon area) (Conil et al., 1982; Poty \& Onoprienko in Shilo, 1984). The stratigraphic comparison of the coral fauna from Belgium with those of the Bristish Isles (Poty, 1983, 1989), N France (Poty \& Hannay, 1994) and Canada (Poty, 2002) came later. The BelgianChinese collaboration of the 1990's led him to focus on coral fauna from SE China both from the stratigraphic and systematic point of view (Poty \& Xu, 1996, 1997; Xu \& Poty, 1997). His interest in Carboniferous stratigraphy was not new at this point as older publications prove (Paproth et al., 1983; Poty, 1984a, 1985; Conil et al., 1991; Poty et al., 2001, 2014), but from the late 1990's on Eddy focused mainly on sequence stratigraphy (Hance et al., 2001, 2002) and biostratigraphy that culminated in a key reference: Poty et al. (2006). Published in the Geological Magazine, it summarizes the power of biostratigraphy coupled to sequence stratigraphy. Naturally, his research on stratigraphy and corals lead him to the Latest Devonian and to the Devonian-Carboniferous boundary and bioevents. Several papers (Poty, 1984b, 1986; Poty \& Boland, 1994; Poty \& Xu, 1996; Poty, 1999) deal with the extinctions and recoveries of corals across the Devonian-Carboniferous boundary. Eddy and collaborators also got interested in the Late Frasnian Crisis and palaeoenvironmental changes across the FrasnianFamennian boundary (Poty \& Chevalier, 2007; Denayer \& Poty, 2010; Mottequin \& Poty, 2016).

Most of his work on Carboniferous corals from the Montagne Noire (Poty et al., 2002), the British Isles (Hance et al., 2002), Poland (Poty et al., 2003), and South China (Poty et al., 2011) remains unpublished to date, as do the Tournaisian corals from Tournai and the Strunian corals of Western Europe, and most of his students' master's theses. Let us hope that he will find time to finally put this 'grey literature' to light soon.

Out of his 105 publications 33 have been published in the Annales de la Société géologique de Belgique and Geologica Belgica, thus $1 / 3$ of his work. This and the several volumes he edited in these journals fully justify this homage volume to be published in this journal.

\section{Selected references}

Aretz, M., Delculée, S., Denayer, J. \& Poty, E. (eds), 2011. 11th International Symposium on Fossil Cnidaria and Porifera - Liège, 19-29 August, 2011, Abstracts Volume; Kolner Forum für Geologie und Paläontologie, 19, 1-202.

Aretz, M. \& Poty, E. (eds), 2011. 11th International Symposium on Fossil Cnidaria and Porifera - Liège, 19-29 August, 2011, Field-Guides; Kolner Forum für Geologie und Paläontologie, 20, 1-201.

Conil, R., Poty, E., Simakov, K.V. \& Streel, M., 1982. Foraminifères, spores et coraux du Famennien supérieur et du Dinantien du massif de l'Omolon (Extrême-Orient soviétique). Annales de la Société Géologique de Belgique, 105, 145-160.

Conil, R., Groessens, E., Laloux, M., Poty, E. \& Tourneur, F., 1991. Carboniferous guide foraminifera, corals and conodonts in the Franco-Belgian and Campine Basins: their potential for widespread correlation. Courier Forschungsinstitut Senckenberg, 130, 15-30.

Denayer J. \& Poty E., 2010. Facies and palaeoecology of the upper member of the Aisemont Formation (Late Frasnian, S. Belgium): an unusual episode within the Late Frasnian crisis. Geologica Belgica, 13/3, 197-212.

Denayer, J., Aretz, M. \& Poty, E. (eds), 2012. Proceedings of the XIth International Symposium on Fossil Cnidaria and Porifera, Liège, Belgium, August 19-29, 2011, Geologica Belgica, 15/4, 200-203.

Hance, L., Poty, E. \& Devuyst, F.-X., 2001. Stratigraphie séquentielle du Dinantien type (Belgique) et corrélation avec le Nord de la France (Boulonnais, Avesnois). Bulletin de la Société géologique de France, 172/4, 411-426.

Hance, L., Poty, E. \& Devuyst, F.-X., 2002. Sequence stratigraphy in the Belgian Lower Carboniferous - Tentative correlation with the British Isles. In Hills, L.V., Henderson, C.M. \& Bamber, E.W. (eds), Carboniferous and Permian of the World. Canadian Society of Petroleum Geologists Memoir, 19, 41-51.

Mottequin B. \& Poty E., 2016 (in press). Kellwasser horizons, sea-level changes and brachiopod-coral crises during the late Frasnian in the Namur-Dinant Basin (southern Belgium): a synopsis. In Becker, R.T., Königshof, P. \& Brett, C.E. (eds), Devonian climate, sea level and evolutionary events. Geological Society Special Publication, 423, doi/10.1144/423.6.

Mottequin, B., Barchy, L., Chevalier, E., Marion J.-M. \& Poty, E., 2012. Aménagement et préservation du patrimoine géologique en province de Liège (Belgique): les géosites d'Ampsin et des Tchafornis (Engis). Annales de la Société géologique du Nord, $2^{\mathrm{e}}$ série, 19, 81-86.

Paproth, E., Conil, R., Bless, M.J.M., Boonen, P., Bouckaert, J., Carpentier, N., Coen, M., Delcambre, B., Deprijck, C., Deuzon, S., Dreesen, R., Groessens, E., Hance, L., Hennebert, M., Hibo, D., Hahn, G., Hahn, R., Hislaire, O., Kasig, W., Laloux, M., Lauwers, A., Lees, A., Lys, M., Op de Beek, K., Overlau, P., Pirlet, H., Poty, E., Ramsbottom, W., Streel, M., Swennen, R., Thorez, J., Vanguestaine, M., Van Steenwinkel, M. \& Vieslet, J.L., 1983. Bio- and lithostratigraphic subdivisions of the Dinantian in Belgium, a review. Annales de la Société Géologique de Belgique, 106, 185-239.

Poty, E., 1975a. Contribution à l'étude du genre Dorlodotia et sa répartition stratigraphique dans le Viséen du bord oriental du Bassin de Namur. Annales de la Société Géologique de Belgique, 98/1, 91-110.

Poty, E., 1975b. Contribution à l'étude des genres Lithostrotion et Siphonodendron du Viséen moyen belge. Annales de la Société Géologique de Belgique, 98/1, 75-90.

Poty, E., 1975c. Un nouveau Tétracoralliaire du Viséen moyen de la Belgique: Corphalia mosae Gen. et sp. nov. Annales de la Société Géologique de Belgique, 98/1, 111-121. 
Poty, E., 1980. Evolution and drowning of paleokarst in Frasnian carbonate at Visé, Belgium. Mededelingen Rijks Geologische dienst, 32/7, 53-55.

Poty, E., 1981. Recherches sur les Tétracoralliaires et les Hétérocoralliaires du Viséen de la Belgique. Mededelingen Rijks Geologische Dienst, 35/1, 1-161.

Poty, E., 1982. Paléokarst et brèches d'effondrement dans le Frasnien moyen des environs de Visé. Leur influence dans la paléogéographie dinantienne. Annales de la Société géologique de Belgique, 105, $315-$ 337.

Poty, E., 1983. Distribution stratigraphique des Tétracoralliaires et des Hétérocoralliaires du Viséen de la Belgique. Annales de la Société géologique de Belgique, 106, 57-68.

Poty, E., 1984a. An evolutionary pattern for the Western European Lithostrotionidae. Palaeontographica Americana, 54, 465-469.

Poty, E., 1984b. Rugose corals at the Devonian-Carboniferous boundary. Courrier Forschunginstitut Senckenberg, 67, 29-35.

Poty, E., 1985. A Rugose coral biozonation for the Dinantian of Belgium as a basis for a coral biozonation of the Dinantian of Eurasia. In Higgs, K. \& Streel, M. (eds), Compte Rendu 10ème Congrès international de Stratigraphie et de Géologie du Carbonifère. Madrid, 1983, 29-31.

Poty, E., 1986. Late Devonian to early Tournaisian Rugose corals. Annales de la Société géologique de Belgique, 109, 65-74.

Poty, E., 1989. Distribution and palaeogeographic affinities of Belgian Tournaisian rugose corals. Memoirs of the Association of Australasian Palaeontologists, 8, 267-273.

Poty, E., 1993. Heterochronic processes in some Lower Carboniferous rugose corals. Courrier Forschunginstitut Senckenberg, 164, 141152.

Poty, E., 1999. Famennian and Tournaisian recoveries of shallow water Rugosa following late Frasnian and late Strunian major crises, southern Belgium and surrounding areas, Hunan (South China) and the Omolon region (NE Siberia). Palaeogeography, Palaeoclimatology, Palaeoecology, 154, 11-26.

Poty, E., 2002. Stratigraphy and paleobiogeography of Carboniferous rugose corals of Nova Scotia. In Hills, L.V., Henderson, C.M. \& Bamber, E.W., (eds). Carboniferous and Permian of the World. Canadian Society of Petroleum Geologists Memoir, 19, 580-587.

Poty, E., 2007. The Avins event: a remarkable worldwide spread of corals at the end of the Tournaisian (Lower Carboniferous). In Hubmann, B. \& Piller, W., (eds), Fossil corals and sponges, Proceedings of the 9th International Symposium on Fossil Cnidaria and Porifera. Schriftenreihe der Erdwissenschaftlichen Kommissionen, Oesterreichische Akademie der Wissenschaften, 17, 231-249.

Poty, E., 2010 Morphological limitation to the diversification of the rugose and tabulate corals. In Kossovaya, O. \& Somerville, I.D., (eds), 10th International Symosium on Fossil Cnidaria and Porifera, Saint-Petersburg, 2007. Palaeoworld, 19, 389-400.

Poty, E. \& Boland, K., 1994. Révision des Tétracoralliaires caninomorphes de l'Hastarien (Tournaisien) belge. Annales de la Société géologique de Belgique, 117/2, 277-301.

Poty, E. \& Chevalier, E., 2004. L'activité extractive en Wallonie: situation actuelle et perspectives. Ministère de la Région wallonne, Jambes, Belgium, $85 \mathrm{p}$.

Poty, E. \& Chevalier, E., 2007. Late Frasnian phillipsastreid biostromes in Belgium. In Alvaro, J.J., Aretz, M., Boulvain, F., Munnecke, A., Vachard, D. \& Venin, E. (eds), Palaeozoic reefs and bioaccumulations: climatic and evolutionary controls. Geological Society Special Publication, 275, 143-161.

Poty, E. \& Hannay, D., 1994. Stratigraphy of rugose corals in the Dinantian of the Boulonnais (France). Mémoires de l'Institut Géologique de 1'Université Catholique de Louvain, 35, 51-82.

Poty, E. \& Onoprienko, Y., 1984. Rugose corals. In Shilo, N.A., Bouckaert, J., Afanasieva, M.J.M., Bless, M.J.M., Conil, R., Erlanger, O.A., Gagiev, M.H., Lazarev, S.S., Onoprienko, Y., Poty, E., Razina, T.P., Simakov, K.V., Smirnova, L.V., Streel, M. \& Swennen, R. Sedimentological and Palaeontological atlas of the Late Famennian and Tournaisian deposits in the Omolon Region (NE USSR). Annales de la Société géologique de Belgique, 107, 200-213.

Poty, E. \& Xu, S., 1996. Rugosa from the Devonian-Carboniferous transition in Hunan, China. Mémoires de l'Institut de Géologie de 1’Université de Louvain, 36, 89-139.

Poty, E. \& Xu, S., 1997. Systematical position of some Strunian and Lower Carboniferous Heterocoral-like colonial corals. Bolletino del Real Societad Española de Historia natural, section Geologia, 92, 99106.

Poty, E., Aretz, M. \& Barchy, L., 2002. Stratigraphie et sédimentologie des «Calcaires à Productus» du Carbonifère inférieur de la Montagne Noire (Massif Central, France). Comptes Rendus Géosciences, 334, 843-848.

Poty, E., Aretz, M., Hance, L., 2014. Belgian substages as a basis for an international chronostratigraphic division of the Tournaisian and Viséan. Geological Magazine, 151/2, 229-243.
Poty, E., Berkowski, B., Chevalier, E. \& Hance, L., 2003. Biostratigraphic and sequence stratigraphic correlations between the Dinantian deposits of Belgium and Southern Poland (Krakow area). In Wong, T.E. (ed.), 15th International Congress on Carboniferous and Permian Stratigraphy, Royal Netherlands Academy of Arts and Sciences, 97106.

Poty, E., Devuyst, F.-X. \& Hance, L., 2006. Upper Devonian and Mississippian foraminiferal and rugose coral zonations of Belgium and northern France: a tool for Eurasian correlations. Geological Magazine, 143/6, 829-857.

Poty, E., Hance, L., Lees, A. \& Hennebert, M., 2001. Dinantian lithostratigraphic units (Belgium). In Bultynck, P. \& Dejonghe, L. (eds), Lithostratigraphic scale of Belgium. Geologica Belgica, 4/1-2, 69-94.

Poty, E., Aretz, M. \& Xu, S., 2011. A comparison of Mississippian colonial rugose corals from Western Europe and South China. In Aretz, M., Delculée, S., Denayer, J. \& Poty, E. (eds), 11th International Symposium on Fossil Cnidaria and Porifera, Liège, Belgium, Abstract volume. Kölner Forum für Geologie und Paläontologie, 19, $135-136$.

Xu, S. \& Poty, E., 1997. Rugose corals near the Tournaisian-Viséan boundary in South China. Bolletino del Real Societad Española de Historia natural, section Geologia, 92, 349-363. 